\title{
Innovation of coffee shop during pandemic COVID-19: Bottled coffee drinks in demand
}

\author{
Dyah Ismoyowati ${ }^{1}$, Shafira Wuryandani ${ }^{1, *}$, Annisa Nala Shinta $^{2}$, Aninda Rizki Amalia ${ }^{2}$ \\ ${ }^{1}$ Lecturer of Agroindustrial Technology, Faculty of Agricultural Technology, Universitas Gadjah \\ Mada, Yogyakarta, Indonesia \\ ${ }^{2}$ Undergraduate Students of Agroindustrial Technology, Faculty of Agricultural Technology, \\ Universitas Gadjah Mada, Yogyakarta, Indonesia
}

\begin{abstract}
Pandemic covid-19 has been influencing the health sector and the business sector worldwide, including coffee shops in Indonesia. Before the pandemic, the coffee shop was one of the most growing businesses in Indonesia that, based on the study, has decreased their revenue up to 50$90 \%$. Nowadays, they are struggling to pass the situation and need to be more innovative and agile. Bottled coffee is a new development, which is coffee shop innovation through this though condition. This article discusses how bottled coffee supports the coffee shop business during the pandemic in Yogyakarta. Ten coffee shop managements are involved in the depth interview in this research. The coffee shop is primarily located in Sleman, Yogyakarta, the most growing coffee shop in Yogyakarta. The result showed that coffee shops are produced bottled coffee right after the pandemic to maintain their business. The coffee shops also give more attention to hygiene and food safety aspects, including cleanliness of kitchen area, packaging, and the quality of coffee taste. They are also forced to use the online method as their media to get more sales.
\end{abstract}

\section{Introduction}

\subsection{Background}

Coffee is an agricultural product that increasingly popular in Indonesia in the last decade. The consumption of coffee in Indonesia is predicted to be increasing by 2023. The number conceived it of coffee shops in most big cities in Indonesia. The coffee shop is the downstream tier in the supply chain of coffee.

Pandemic COVID-19 has influenced the health sector and the business sector worldwide, including coffee shops in Indonesia. Before the pandemic, the coffee shop was one of the most growing businesses in Indonesia that, based on the study, has decreased their revenue up to 50-90\%. In addition, based on McKinsey (2020), Indonesian consumer lessens their food consumption, especially their dine-in habit, over 58\%[1]. This reduction is the problem that needs innovation.

* Corresponding author: shafira.wuryandani@ugm.ac.id 
Nowadays, they are struggling to pass the situation and need to be more innovative and agile. Some methods that coffee shops adopted to adapt to the situation are online selling and delivery service. Regarding McKinsey, 50\% of consumers shifted to online buying and delivery during the pandemic [1]. Therefore, some of the coffee shops combine those methods with another strategy, bottled coffee.

Bottled coffee is a new development, which is coffee shop innovation through this though condition. This idea is presumed because of the change in consumer behavior. Most consumers thought that buy more would be more efficient during this pandemic. To better understand this problem, factors influencing the changing behavior are discussed in this article. The purpose of this article is to understand how bottled coffee supports the coffee shop business during the pandemic in Yogyakarta.

\subsection{Coffee}

Coffee is one of the leading plantation commodities in Indonesia and has a relatively high economic value compared to other plantation commodities. The role of coffee commodities for the Indonesian economy is essential, both as a source of income for coffee farmers, a source of foreign exchange, a producer of industrial raw materials, and a provider of employment through processing, marketing, and trade (exports and imports). Based on the International Coffee Organization (ICO) data, Indonesia is one of the fourth most significant producers and exporters of coffee beans worldwide after Brazil, Vietnam, and Colombia [2]. It is supported by data obtained from the General of Plantations, which states that coffee production in Indonesia has increased from 2016 to 2020 [3]. In 2016, from 34 provinces in Indonesia, coffee production reached 663,871 tons, and it is estimated that in 2020 it will increase to 773,409 tons. The type of coffee that dominates coffee production in Indonesia is the Robusta type of coffee at $81.87 \%$, and the rest is the Arabica type at $18.13 \%$ [4]. Various types of coffee are served in coffee shops in Indonesia. Espresso, latte, cappuccino, and mochaccino are coffee drinks offered in coffee shops.

\subsection{Coffee Shop}

A coffee shop is a multifunctional place for its consumers. In the beginning, a coffee shop was designed for coffee lovers to taste their cup of coffee while relaxed. However, the development of culture and generations changed the function of the coffee shops. As a result, coffee shops become a communication place for groups. Every consumer can use the coffee shop as a medium to determine the various roles of satisfaction, pleasure, prestige, and needs [5]. In Europe, coffee shops played a vital role in the political awareness of young people. The revolution in Bosnia-Herzegovina is an example of the coffee shop role where the political movement emerged from simple chats in coffee shops [6].

The shifting role of the coffee shop made the concept of consumer experience has emerged for coffee shop service. It happened to achieve more consumer engagement, which will affect customer loyalty. The new trend of the coffee shop is to have a strong brand and serve customers in a unique way. A study resulted that the primary determinant models for coffee consumption can be grouped into four categories (1) personal preferences, (2) economic attributes, (3) product attributes, (4) consumption context, and (5) sociodemographic. These findings also indicate a strong focus on coffee sustainability [7].

\subsection{Bottled coffee}

Bottled coffee is product innovation in coffee shops in Indonesia in order to survive during the pandemic. Bottled coffee is a coffee drink packaged in bottled, usually in $500 \mathrm{ml}$ and 
$1,000 \mathrm{ml}$, and can be used as supplies in the refrigerator for several days [8]. In addition, the use of bottled packaging makes it easier to deliver. There is a various variant of bottled coffee: coffee latte, flavored coffee, and cold brew.

\section{Methods}

Through online data collection, coffee shops are identified by compiling a list of coffee shops that offer bottled coffee products in Sleman, Yogyakarta. Sleman Regency is chosen because it has the most significant coffee shops among other regencies in Yogyakarta Province. The determination of the coffee shop object used purposive sampling with Google Review using two criteria; (a) has a rating given by consumers 4.0 out of 5 stars; (b) has more than 50 reviews.

The survey also collected information from consumers who buy bottled in Yogyakarta coffee during the pandemic. Respondents answered online questions about their purchase behavior of bottled coffee due to the pandemic Covid-19. The sample is determined by the purposive sampling method.

Five coffee shop managements are involved in the depth interview in this research. The coffee shop is primarily located in Sleman, Yogyakarta, the most growing coffee shop in Yogyakarta. One hundred consumers joined the survey who buy bottled coffee in the coffee shop in Yogyakarta during large-scale social restrictions (March 31, 2020 - June 30, 2020) and the new normal era (July 1, 2020 - 2021).

\section{Results and Discussion}

\subsection{Pandemic effects on coffee shop}

The consumption sector primarily supports Indonesia's economy. The pandemic Covid-19 that started in the first quarter of 2020 caused the Indonesian economy to experience a decline in the consumption sector. It leads the collapse of businesses, one of which was a coffee shop. The results of this study are expected to be helpful information to increase coffee shop sales during the pandemic to improve the economy during the pandemic.

Most of the coffee shop management said that there are significant effects on decreased sales during this pandemic. Some reasons lead this sales reduction. First, the Government's large-scale social restrictions resulted in a reduction in coffee shop operating hours. Initially, most coffee shops operate from morning to midnight. However, since the pandemic, operating hours have been from morning tonight. Second, apart from reducing operating hours, the dine-in capacity at the coffee shop was also reduced by $50 \%$, following the Government's regulations. An example of a coffee shop should reduce their availability from 24 to 12 consumers dine-in.

In addition, some coffee shops with co-working space lost their co-working space tenant when the outbreak started. Most tenants moved out because the Government advised them to work from home. It made their sales jumping down.

According to the managers, coffee shops where their target market is students and foreigners, their customers reduced up to $70 \%$. Universities and schools are closed and asked their student to stay at home to minimalize the virus transmission. Universities and campuses are moving toward online education. Moreover, the number of foreigners who came be on vacation to Yogyakarta diminished due to flight closures and restrictions from some countries. Countries around the world are increasingly adopting sweeping measures, including full lockdowns, shutting down airports, imposing travel restrictions, and 
completely sealing their borders to contain the new coronavirus [9]. It proved that Covid-19 also has a large destructive impact on the tourism industries [10].

A coffee shop manager claims its turnover has fallen by $90 \%$; other managers said its turnover has decreased by $50 \%$. It is pretty reasonable and relates to the reduction in operating hours and capacity of the coffee shop. It does not just happen to the coffee shop business either. Other businesses, especially SMEs in Indonesia, decreased their gross income by $41.6 \%$ and lost profit level $62.8 \%$ in general [11]. Another survey found that $69 \%$ of SMEs experienced a decrease in sales turnover [12].

Pandemic also impacted on reducing the employment of the coffee shop. A coffee shop management from the survey should reduce their employee to survive their business. Reduced workforce meant that workload had to be distributed to remaining employees. It can result in health and workload concerns of the employee [13].

Another thing that has led to a decrease in coffee shop visitors during the pandemic is consumer concerns about covid-19. Consumers are still worried about being exposed to Covid-19 if they make visits to coffee shops. A survey on the attitude towards Covid-19 in 1,354 Indonesian residents found that $76,4 \%$ of residents stated that they were feeling anxious being infected with SARS-CoV-2 [14]. By 15 June 2021, there are 1,919,547 coronavirus cases with 53,116 deaths [15]. It makes Indonesian still hesitant to dine in.

During the pandemic Covid-19, the coffee shop management offered hygiene practices. They performed effective cleaning practices in coffee shops once a week. They also forced their customer and staff always to wear the mask. The coffee chops management also provided hand washing facilities and hand sanitizer. Physical distancing advice is provided using stickers and markers inside the coffee shops. Consumers in Indonesia revealed a good level of food safety knowledge, positive attitudes. They reported frequent hand hygiene practices, cleaning \& sanitizing, and adherence to social distancing measures while dining in. Therefore, enough support from restaurant and hand washing facilities is critical to adherence to hand hygiene and social distancing measures when dine-in [16].

\subsection{The strategy of the coffee shop during the pandemic Covid-19}

All coffee shop managers launched literary coffee during the pandemic as one of their marketing strategies. This bottled coffee was launched to provide coffee for consumers who want to consume coffee with their families at home. A survey in Yogyakarta on August 2020 found that $52 \%$ consumers preferred to consume coffee at home rather than in coffee shop [17]. This literary coffee is considered to be one of the strategies that can increase purchases so that coffee shops can survive during a pandemic.

As for bottled coffee, coffee shop managers have also launched various new products such as frozen food, bundling promos, maximizing the use of go-food and grab-food. Bottled coffee is a new product that launched during the pandemic for market target people who work from home and want ready to drink coffee. Bottled coffee products are dominated by milk-based coffee, such as kopi susu basic, kopi susu gula aren, vanilla latte.

This new product is also used as holiday gifts offered to their customers. In Indonesia, holidays like Idul Fitri or Christmas are special moments to share. Usually, Indonesians will send gifts to each other as a greeting of joy. So the coffee shop management saw this as an opportunity to boost their sales by selling bottled coffee gifts.

Besides, the coffee shops used online platforms like Go-food and Grab food to help to increase their sales. The use of that kind of platform is helpful during the pandemic since everyone can get their food without the need to going out. In addition, coffee shop management used social media to promote their products. It helps customers to find product information and attract them to buy. Adopting that kind of technology is increasing in Indonesia, both on the customer and business side. Research about digital technologies 
adoption in SMEs in Indonesia revealed that businesses face a competitive market and have a higher probability of adopting digital technologies [18].

The strategy of the coffee shop during the pandemic seems to be successful ways to increase the business activity and profit. However, some reasons make consumers have the willingness to eat out in the coffee shop. It is in accordance with the research that found consumers' perception and trusted sources of food safety information during the pandemic. Consumers were more worried about infected Covid-19 from people than food. They also believed hand washing is more protective for Covid-19 than foodborne disease [19,20]. It described why consumers have started to dine in the new normal era while the restaurants provide adequate hand washing facilities and social distancing areas. Other research found that most consumers' purchase reason to eat out was quality, availability, and convenience [21].

\subsection{Coffee shop consumer behavior during the pandemic Covid-19}

In order to understand the consumer behavior during the pandemic related to their consumption of bottled coffee, the study held a consumer survey. The survey is done online through consumers who bought bottled coffee during the pandemic in Yogyakarta. There are 100 respondents involved in the survey. Respondents ask about their behavior related to bottled coffee consumption.

From the survey, most respondents are men (67\%). The majority of the respondents are aged 18-25. It means that they were born during 1996-2012. Based on Generational Theory, the age group is called Generation Z (Gen Z) [22]. Gen Z has character to be more realistic and needs security and stability [23]. Gen Y and Gen Z dominated to create new life style of coffee consumption.

The respondents dominantly (57\%) have income around IDR 600,000.00-IDR $1,900,000.00$ (approx. USD 42 - USD 132). It is related to their occupation that most university students $(72 \%)$. It also related to the regional minimum wage per month in Yogyakarta is around IDR 1,700,000.00 (USD 120) so that the most respondents have the income in that range.

\section{Purchasing Time of Bottled Coffee}

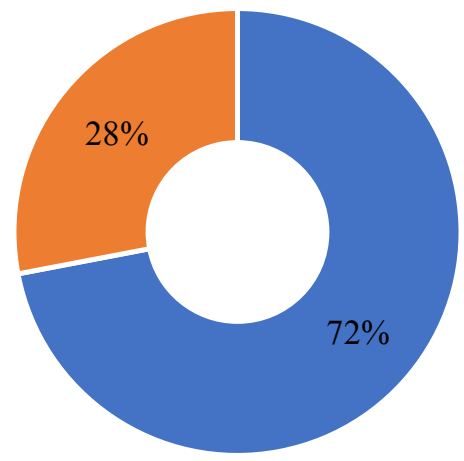

- During new normal (July 1, 2020 - 2021)

- During the large-scale social restrictions (March 31, 2020

- June 30, 2020)

Fig. 1. Purchasing time of Bottled Coffee

$72 \%$ of consumers bought bottled coffee from the survey during the new normal period, which started from July 1, 2020, to 2021. In contrast, the rest of the respondents 
bought bottled coffee during the large-scale social restrictions announced by the Indonesian Government from March 31, 2020, to June 30, 2020. Most consumers stated that they in Indonesia still afraid of consuming food from outside their house during the large-scale social restrictions. So, it makes sense that most of them buying bottled coffee during the new normal era where the restriction was not applicable.

\section{Preferred variants of bottled coffee}

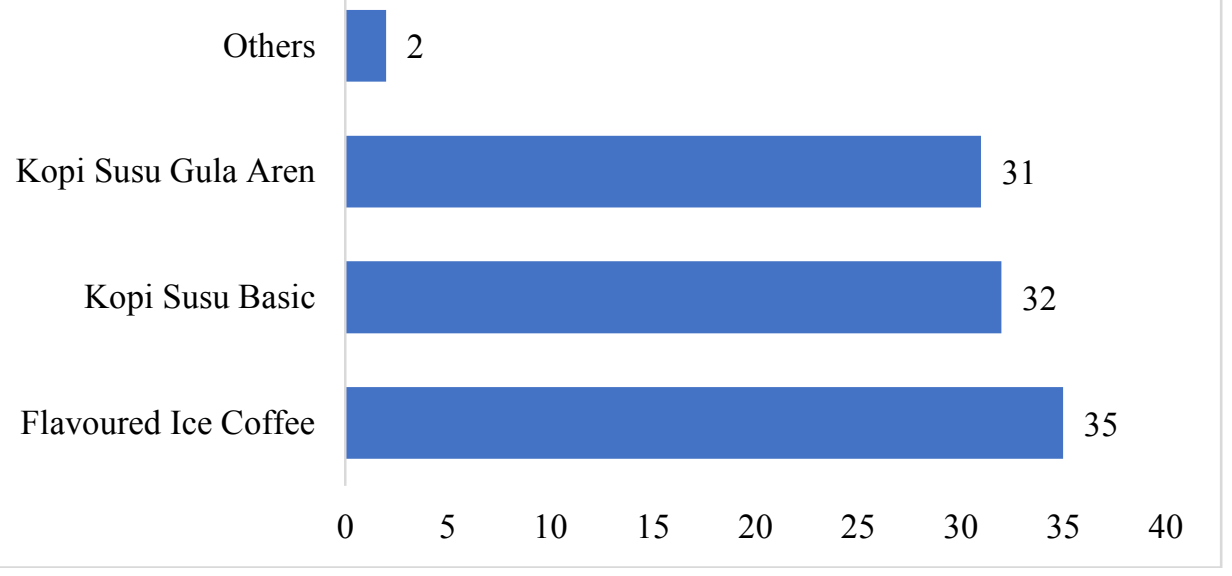

Fig. 2. Preferred variants of bottled coffee

The survey also asked respondents about their chosen variants that can be seen in Figure 2. Thus, it represented the consumer preferences of bottled coffee. There are many bottled coffee variants. The most purchased bottled coffee is flavored ice coffee. It contains a coffee blend with milk, sugar, and any flavor such as vanilla, hazelnut, and caramel. The other variants that consumers also bought are kopi susu basic. It is a coffee blend with milk. Another variant, kopi susu gula aren is a coffee blend with milk and brown sugar. Both are coffee drinks that popular in Indonesia in the last three years.

The $500 \mathrm{ml}$ package is the most preferred for consumers. The $1,000 \mathrm{ml}$ bottled coffee could be too much for a person to consume daily. Most consumers (74\%) purchased 1-2 times bottled coffee in a month. They also preferred buying online (64\%) via Grab food and Go-food than take away to the coffee shop.

\section{Conclusions}

The focus of the study is to discuss how bottled coffee supports the coffee shop business during the pandemic in Yogyakarta. This paper is a preliminary study of the consumer behavior of bottled coffee consumers during the pandemic COVID-19.

The result showed that pandemic affected coffee shop businesses and consumers in Yogyakarta, Indonesia. Then, the coffee shops are produced bottled coffee right after the pandemic to maintain their business. The coffee shops also give more attention to hygiene and food safety aspects, including cleanliness of kitchen area, packaging, and the quality of coffee taste. Pandemic enforced business sector and consumers to use the online method more aggressively for a transaction.

The results of this study are helpful for coffee shop management to recognize their consumers and to innovate to maintain their business. This research has limited area 
coverage and sources. Research with a wider and in-depth coverage is expected to better picture the coffee shop business during the pandemic in Indonesia.

The authors received no financial support for the research, authorship, and/or publication of this article.

\section{References}

1. A. Potia and D. Praseco, McKinsey (2020).

2. Direktorat Jenderal Perundingan Perdagangan Internasional, (2018).

3. Direktorat Jenderal Perkebunan, (2020).

4. Badan Pusat Statistik, (2019).

5. G. Joelita and E. Putri, AntroUnairDotNet 2, 124 (2013).

6. A. Jeffrey, L. A. Staeheli, C. Buire, and V. Čelebičić, Polit. Geogr. 67, 125 (2018).

7. H. Vanharanta, J. Kantola, and S. Seikola, Procedia Manuf. 3, (2015).

8. N. Azizah, (n.d.).

9. AL JAZEERA, (n.d.).

10. M. Skare, D. R. Soriano, and M. Porada-Rochon, Technol. Forecast. Soc. Chang. 163, (2021).

11. K. R. Suryani, R. Zulfikar, and A. Vitria, Int. J. Sci. Technol. Manag. 2, (2021).

12. E. T. Prasetyo, L. Muniroh, H. Halin, and W. Winarso, Solid State Technol. 63, 4020 (2020).

13. A. Al-Fadly, Entrep. Sustain. Issues 8, 629 (2020).

14. Z. S. Ulhaq, R. A. Kristanti, A. A. Hidayatullah, L. N. Rachma, N. Susanti, and A. Aulanni'am, Data Br. 32, (2020).

15. Wedometer, (n.d.).

16. J. Mei, I. Vanany, I. Rahayu, A. Wahab, and R. Hayati, Food Control 125, 107920 (2021).

17. S. Azmi, (2020).

18. I. Trinugroho, P. Pamungkas, and J. Wiwoho, Financ. Res. Lett. 102156 (2021).

19. M. S. Thomas and Y. Feng, Food Control 108279 (2021).

20. K. Byrd, E. Her, A. Fan, B. Almanza, Y. Liu, and S. Leitch, Int. J. Hosp. Manag. 94, 102821 (2021).

21. L. Eger, L. Komarkova, D. Egerova, and M. Micik, J. Retail. Consum. Serv. 61, (2021).

22. D. Pendergast, Fam. Consum. Sci. Res. J. 37, 504 (2009).

23. D. Gandasari and D. Dwidienawati, Heliyon 6, e05599 (2020). 